В. М. Манько // Соціалізація особистості. - К. : Логос, 2000. - Вип. 2. - С. 153-161. 11. Організація самостійної роботи студентів в умовах інтенсифікації навчання: [навч. посіб.] / А. М. Алексюк, А. А. Аюрзанайн, П. І. Підкасистий, В. А. Козаков та ін. - К. : ІСДО, 1993. - 336 с. 12. Перспективи розвитку коледжів і технікумів [Електронний ресурс] / Доповідь Заступника Міністра освіти і науки на нараді голів Рад директорів вищих навчальних закладів I-II рівнів акредитації України. - Режим доступу : http://www.mon.gov.ua. 13. Пометун О. I. Інтерактивні технології навчання : [наук.-метод. посіб.] / О. І. Пометун, Л. В. Пироженко. - К. : «А. С. К.», 2005. - 192 с. 14. Стасюк В. Д. Педагогічні умови професійної підготовки майбутніх економістів у комплексі «школа - вищий заклад освіти»: дис. ... канд. пед. наук: 13.00.04 / В. Д. Стасюк. - Одеса, 2003. - 282 с.

\title{
СТРУКТУРУВАННЯ ЗМІСТУ КУРСУ «ГАРМОНІЯ» ЗА КРЕДИТНО-МОДУЛЬНОЮ ТЕХНОЛОГІЕЮ У ВИЩИХ НАВЧАЛЬНИХ ЗАКЛАДАХ
}

Ярошенко О. М. Структурування змісту курсу «Гармонія» за кредитно-модульною технологією у вищих навчальних закладах.

У статті розкриваються практичні шляхи структурування навчального матеріалу курсу «Гармонія» в системі фахової підготовки вчителя музичного мистецтва за кредитно-модульною технологією навчання. Висвітлено зміст курсу відповідно до навчальних елементів схеми 3 гармонії (музичні явища, модулі), елементів філософсько-культурологічної спрямованості (епохи мистецтва, розуміння світу людиною), що перебувають між собою в ієрархічній залежності.

Ключові слова: структурування навчального матеріалу, кредитно-модульна технологія, курс гармонії, методи моделювання змісту, елементи інтеграції.

Ярошенко Е. Н. Структуризация содержания курса «Гармония» с использованием кредитно-модульных технологий в высших учебных заведениях.

В статье раскрываются практические пути структуризации учебного материала курса «Гармония» в системе профессиональной подготовки учителя музыкального искусства в соответствии с кредитно-модульной технологией обучения. Освещено содержание курса в соответствии с учебными елементами схемы по гармонии (музыкальные явления, модули), елементами философско-культурологической направленности (эпохи искусства, понимания мира человеком), которые пребывают между собой в иерархической зависимости.

Ключевые слова: структуризация учебного материала, кредитно-модульная технология, курс гармонии, методы моделирования содержания, элементы интеграции.

Yaroshenko O. M. Structuring of the contents of the course «Harmony» according to creditmodul system in institutions of higher education.

The article dwells on practical ways of structuring the material of the learning course «Harmony» in the system of music teachers training pursuant to credit-modular technology of education. The paper deals with the course content according to the learning circuit elements of harmony (musical phenomenon modules), elements of philosophical and cultural orientation (the era of art, human understanding of the world) that abide in hierarchical dependence.

Key words: structuring of academic material, credit-modul system, course of harmony, methods of modeling contents, elements of integration.

Інтеграція України до світового товариства активно впливає на педагогічний процес. Традиційні методи навчання змінилися на новітні дидактичні технології, однією 3 яких є модульне навчання. Із дисциплін музично-теоретичного циклу кредитно-модульне навчання відбувається в аспекті оптимальної структуризації навчальних програм та використанні модульно-рейтингової оцінки знань студентів. Актуальність структурування навчального матеріалу за кредитно-модульною технологією зумовлена підвищенням рівня підготовки фахівців, удосконаленням змісту знань студентів шляхом перетворення загальноприйнятої моделі вивчення гармонії з урахуванням альтернативного підходу до професійної діяльності підготовки вчителя музичного мистецтва. 
Гармонія входить до циклу навчальних теоретико-музичних дисциплін професійної предметної підготовки освітньо-кваліфікаційного рівня «бакалавр» за спеціальністю 6.020204 «Музичне мистецтво» напряму 0202 «Мистецтво». Дисципліна «Гармонія» у вищих навчальних закладах є складником професійної підготовки студентів, одним із провідних предметів циклу музично-теоретичних дисциплін, який забезпечує вивчення основних компонентів музичної мови. Курс гармонії значною мірою зосереджує увагу на питаннях розвитку і логіки організації та розгортання звукової тканини за вертикальним та горизонтальним спрямуванням, внутрішніх закономірностей і зв'язків. Метою вивчення предмета $є$ розвиток гармонійного слуху, композиторських здібностей, виявлення інтересу до творчості. Окрім формування в студентів стійких практичних навичок аналізу музичної тканини, гармонізації мелодії, грі секвенцій, модуляцій, курс гармонії у системі вищої освіти повинен сформувати у студентів уміння визначати характерні риси стилю тієї чи іншої епохи, композитора, навіть окремого музичного твору. Тому великого значення для студента в процесі вивчення дисципліни набуває глибоке усвідомлення принципів організації музичної системи, процесу історичного становлення і розвитку гармонічного мислення, акордової функціональності в неподільній єдності з іншими елементами музичної мови, становленню професійних якостей студента, що забезпечуються оптимальною побудовою навчального матеріалу курсу.

Метою статті є аналіз проблеми структурування навчального матеріалу з гармонії, зокрема методів його структурування за кредитно-модульними технологіями навчання у вищих навчальних закладах.

Особливості організації навчального процесу підготовки фахівців за вимогами ESTS розглядаються в роботах багатьох науковців (В. Бех, Я. Болюбаш, В. Грубінко, Б. Левківський, Ю. Малиновський, Т. Рейзенкінд). У музичній педагогіці проблему кредитно-модульного навчання досліджують С. Горбенко,В.Клин, Л. Масол, Н. Палій, Г. Падалка, О. Шрамко, О. Щолокова та ін. У цих працях зазначаються напрямки конструювання змісту модульного навчання [4], пропонуються зразки певних алгоритмів у процесі підготовки вчителя музичного мистецтва, відбивається пошук оптимальних шляхів інтеграції новітніх і традиційних підходів до програмного та методичного забезпечення дисциплін мистецького циклу [8]. Водночас варто констатувати недостатню кількість розроблених програм, навчально-методичних комплексів із дисциплін музично-теоретичного циклу. Виникнення суперечностей між необхідністю забезпечення модульного навчання на практичних заняттях із гармонії i недостатнім розробленням цього питання у ВНЗ зумовило актуальність окресленої роботи [9, с. 366].

Для побудови логічної структури навчального матеріалу з гармонії звернемось до проблеми структурування змісту навчального матеріалу в педагогічних дослідженнях та визначимо напрямки і засоби структурування змісту навчання музичних технологій. Теоретичному питанню структурування навчального матеріалу в сучасній педагогіці приділяється велика увага (В. Беспалько, Н. Брюханов, О. Коваленко, Я. Скалков, А. Сохор, А. Ерднієв). Шляхи оптимальної побудови навчального матеріалу інтенсивно вивчалися науковцями (В. Бондар, І. Булах, П. Гусак, В. Пащенко, О. Чалий). Дослідження в цій галузі свідчать, що науково впорядкований зміст навчальної дисципліни засвоюється більш ефективно (Л. Барсукова, С. Бутаков, О. Подольська). Усвідомлення структури матеріалу та його внутрішніх логічних взаємозв'язків забезпечують розуміння предмета, діалектики розвитку його понять [3, с. 21]. Водночас спеціалісти в галузі музичної освіти часто звертають увагу на недостатній рівень упорядкованості навчального матеріалу в реальній практиці навчання.

Аналіз праць із теми дослідження дозволив 3'ясувати, що вибір методів, які сприяють оптимізації педагогічного процесу за модульно-рейтинговою технологією, визначається дидактичними принципами і цілями, що зумовлюють поетапність засвоєння навчальної інформації. Досліджуючи різні підходи до структурування навчального матеріалу: інтерактивний принцип змісту освіти (Я. Скалковим), укрупнення дидактичних одиниць (А. Ерднієвим), принцип тематичної концентрації змісту (Е. Страчар), ми виявили єдину їх сутність структурувати навчальний матеріал так, щоб усі поняття, визначення, явища поєднувались в одну систему і доповнювали одне одного за умови відсутності як надлишкової спресованості, так i надмірної розтягнутості в часі засвоєння взаємопов'язаних компонентів [2]. Головне завдання, як правило, полягає в проектуванні та розробленні чіткої логічної структури навчального матеріалу. 
Спираючись на наукові дослідження, присвячені окресленій проблемі, ми визначили методи побудови логічної структури змісту навчального матеріалу, у яких перевага віддається використанню методів моделювання: матричному методу i методу графів. Метод структурування змісту навчання, згідно з позицією В. Безпалько, - логічна структура на основі ієрархічної побудови «навчальних елементів» (змістових модулів, їх взаємозв'язків) [1] має багато спільного з методом графів, визначеним А. Сохором: «для структурного... аналізу навчального матеріалу великого значення набуває вибір способу моделювання, що дозволяє зобразити структуру зв'язків між логічними елементами матеріалу» [7, с. 64]. На думку багатьох науковців, схеми, зокрема графи, дозволяють легше виявляти та відтворювати логічні зв'язки між поняттями навчального матеріалу.

Першим етапом структурування змісту навчального матеріалу $є$ ретельний аналіз його логічної структури. Визначаються базові поняття та зв'язки між ними. Наступний крок передбачає побудову моделі курсу у формі графу відповідно до структурно-логічних явищ і понять дисципліни та виокремленні простих циклів на основі базових понять. Для побудови моделі навчального матеріалу з гармонії за кредитно-модульною технологією ми використали теорію графів, отримавши структурно-логічну схему курсу з фундаментальними поняттями. При цьому ми керувались принципами концентрації навчального матеріалу навколо провідних понять, поєднанням логічного та історичного аспектів у навчальному пізнанні (Рис.1).

Зі структурно-логічної схеми можна констатувати, що навчальні елементи схеми з гармонії (музичні явища, модулі), елементи філософсько-культурологічної спрямованості (епохи мистецтва, розуміння світу людиною) перебувають між собою в ієрархічній залежності. Більш складні навчальні елементи грунтуються на нижчих вихідних ієрархічних рівнях. Таке графічне представлення логічної структури змісту теоретико-гармонічного навчання 3 обов'язковим мотивуванням потреби кожного включеного до її складу навчального елементу (гармонічних явищ, змістових модулів, модульного контролю) надасть можливість візуально охопити всі змістові модулі, практичні компоненти, ракурси еволюції гармонії та взаємні зв'язки між ними. Важливо, що орієнтація на крупніші одиниці гармонічного мислення певної епохи дає змогу охопити число дрібних одиниць практичної спрямованості (акордів, гармонічних зворотів тощо). Як уважає М. Скаткін, граф-схема, яка показує ієрархію всіх компонентів змісту (у нашому випадку мистецької епохи, розуміння світу і людини, гармонічного явища, змістових модулів), надає змогу строго проконтролювати необхідність і місце кожного гармонічного періоду з відповідними поняттями і зворотами в загальній логічній структурі курсу [6, с. 42].

Програма дисципліни гармонії передбачає розподіл навчального матеріалу на змістові модулі 3 відповідною кількістю залікових кредитів на кожен семестр. Змістовий модуль $є$ цілісним навчальним об'єктом 3 визначеною кількістю аудиторних та самостійних форм роботи, які розкривають зміст модуля, теоретичні знання та практичні уміння і навички, які студент повинен отримати. Курс гармонії складається із лабораторних занять (140 год.) та самостійної роботи студентів (184 год.), що за структурою програми становить 9 кредитів, відповідних ЕСТS, та 6 змістових модулів (зазначені у схемі). Курс поділяється на такі структурні розділи: заліковий кредит курсу, теоретичну частину (програма курсу), практичну (плани лабораторних занять, завдання для самостійної роботи, завдання модульного контролю) і результативну (форми рейтингового контролю, методика розрахунку рейтингу, вимоги до екзамену) частини. Важливо, що в завданнях модульного контролю за дворівневим ступенем ураховується індивідуалізація процесу навчання за модульно-рейтинговою технологією, яка пов'язана 3 такими індивідуальними відмінностями студентів, як характер перебігу процесів мислення, рівень знань і вмінь, працездатності.

Структурування змісту навчального матеріалу (за дослідженнями А. Бойко, К. Волинця, Л. Хомич) може відбивати проекцію його на відповідні історичні періоди розвитку людства в тих чи тих аспектах. У запропонованій моделі змісту навчального матеріалу розвиток гармонічного мислення розглядається в аспекті світорозуміння, порівнюється з еволюційним процесом людини, що забезпечує дидактичний принцип поєднання логічного та історичного в навчальному пізнанні.

Так, згідно з стандартами вищої освіти, навчальний матеріал курсу гармонії акцентує увагу студентів (у першу чергу з відповідним рівнем фахової підготовки) на можливостях інтегрованого підходу у викладанні знань з історії гармонії, що забезпечує високий рівень узагальнень і широке перенесення їх до інших дисциплін музикознавчого і культурологічного циклів. 


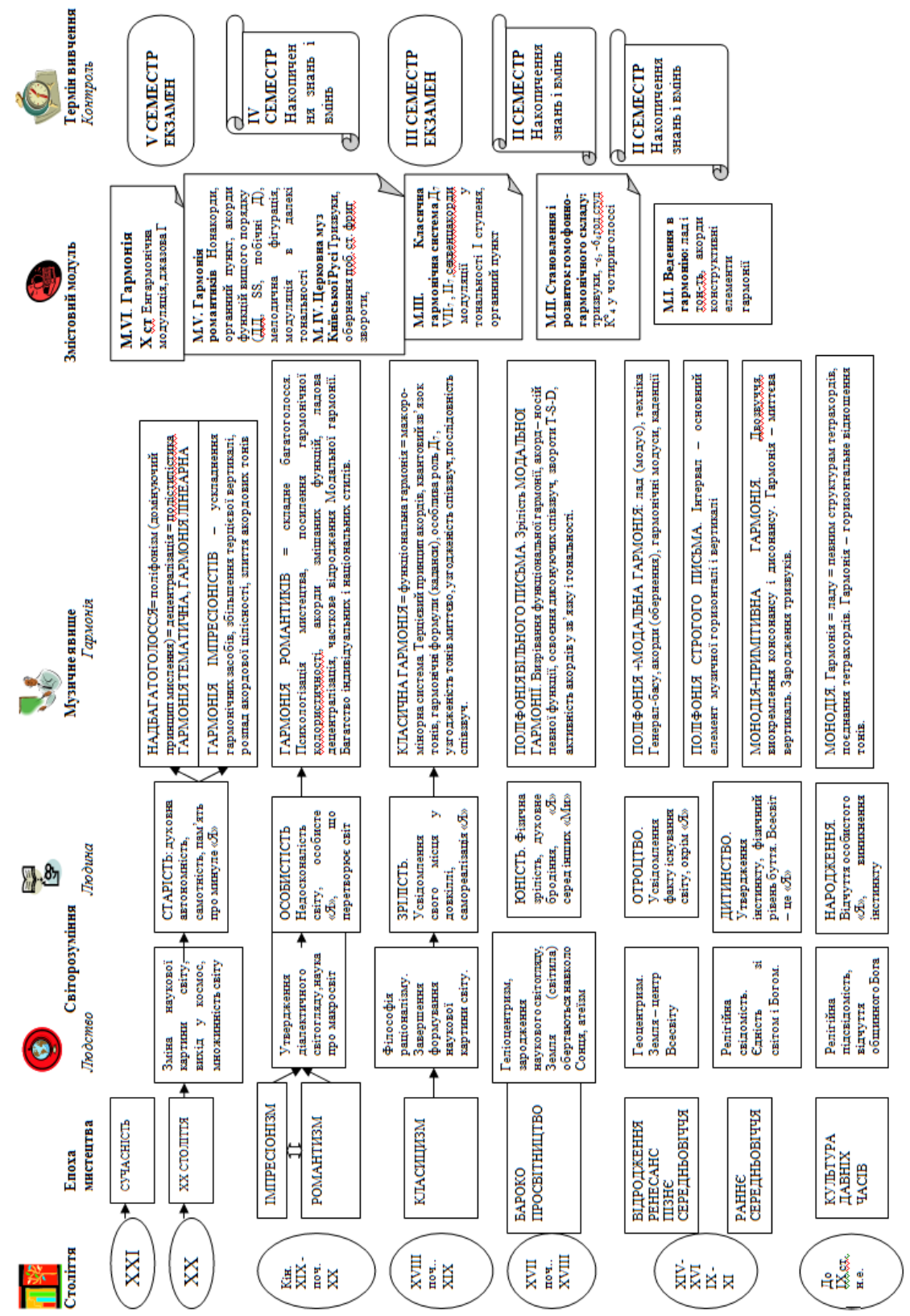

Рис 1. Структурно-логічна схема змісту навчального матеріалу з курсу «Гармонія» за вимогами кредитно-модульного навчання 
Модернізація змісту гармонії полягає у збагаченні програми загальнооглядовими питаннями 3 історії становлення і розвитку гармонічних засобів. Ці питання, як доводить досвід роботи, цікавлять не тільки теоретиків і музикознавців, але можуть стати опорним інструментом на шляху поглиблення фахових компетенцій майбутніх учителів мистецьких дисциплін [5]. Виходячи 3 розрахунку визначених навчальним планом годин для аудиторної роботи з гармонії, більшість тем, які пов'язані 3 історією становлення і розвитку гармонії, винесена на самостійне опрацювання. Наприклад, теми, пов'язані з раннім багатоголоссям, модальною і тональною гармонією, мажоро-мінорною системою у XVII-XIX століттях, музичною культурою Київської Русі, становленням гомофонно-гармонічного мислення в українських народних піснях, розвитком i поглядами музикознавців щодо функціональної теорії, тональної системи в еволюції гармонічного мислення тощо. Як показала практика, програма 3 елементами інтегрованого підходу сприяє цілісності знань з музично-теоретичних дисциплін в цілому та $є$ запитаною у практичній діяльності майбутнього вчителя музичного мистецтва.

Упровадження до курсу гармонії інтегрованого підходу щодо розгляду практичних понять в аспекті еволюції гармонічного мислення від першоджерел до руйнації тональної системи, втіленої у відповідній структурі матеріалу (теоретичному, практичному, самостійних видах робіт), надає студентам змогу оволодіти професійними знаннями, сформувати необхідні вміння і навички, задовольнити вимоги базової вищої освіти стосовно обсягу засвоєння навчального матеріалу. Науковий інтерес до дисципліни допомагає майбутнім педагогам не втрачати наукової культури, учити учнів бачити зв'язок дисципліни із загальними процесами людського розвитку. Перспективи подальших розвідок полягають в екстраполяції отриманих результатів у процес викладання інших предметів, тобто забезпеченні міждисциплінарних зв'язків i цілісності навчання, уведенні додаткових гармонічно-інформаційних контурів між поняттями, що внесені до вже створених контурів графу.

\section{Література}

1. Беспалько В. П. Слагаемые педагогической технологии / В. П. Беспалько. - М. : Педагогика, 1989. - 190 с. 2. Гусак П. М. Історія педагогіки: [навч. посіб.] / П. М. Гусак, А. А. Мартіросян. Луцьк: РВВ «Вежа» ВДУ ім. Лесі Українки, 1996. - 166 с. 3. Наука - вуз - школа: [сб. науч. тр. молодых исследователей]. - Магнитогорск, 2000. - Вып. 6. - С. 21. 4. Падалка Г. М. Пріоритетні напрямки розвитку сучасної мистецької освіти / Галина Микитівна Падалка // Науковий часопис Національного педагогічного університету ім. М. П. Драгоманова. Серія 14. Теорія і методика мистецької освіти: зб. наук. праць. Вип. 1(6). - К. : НПУ, 2004. - С. 15-20. 5. Рейзенкінд Т. Й. Дидактичні основи професійної підготовки вчителя музики в педуніверситеті: [монографія]/ Т. Й. Рейзенкінд. - Кривий Ріг: Видавничий дім, 2006. - 640 с. 6. Скаткин М. Н. Совершенствование процесса обучения: [пособие] / Михаил Николаевич Скаткин. - М. : Педагогика, 1971. - 206 с. 7. Сохор А. М. Логическая структура учебного материала. Вопросы дидактического анализа / А. М. Сохор. - М. : Педагогика, 1974. - 192 с. 8. Шрамко О. І. Основний музичний інструмент: алгоритми методики: [навч.-метод. посіб.] / Оксана Іллівна Шрамко. - Кривий Ріг: Видавничий дім, 2008. - 219 с. 9. Ярошенко О.М. Методика застосування кредитно-модульного навчання в процесі викладання гармонії на практичних заняттях у вищих навчальних закладах / О.М.Ярошенко// Педагогічна майстерність як система професійних і мистецьких компетентностей: зб. матеріалів VII мистецько-педагогічних читань пам'яті проф. О. П. Рудницької; [за ред. О. М. Отич] / Олена Миколаївна Ярошенко. - Чернівці: Зелена Буковина, 2010. - С. 364-373. 